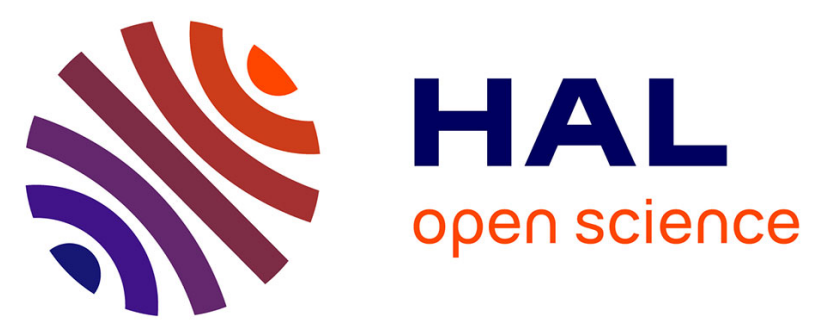

\title{
Aberrant gene expression patterns in placentomes are associated with phenotypically normal and abnormal cattle cloned by somatic cell nuclear transfer
}

Robin E. Everts, Pascale Chavatte-Palmer, Anthony Razzak, Isabelle Hue, Cheryl A. Green, Rosane Oliveira, Xavier Vignon, Sandra L. Rodriguez-Zas, X.Cindy Tian, Xiangzhong Yang, et al.

\section{To cite this version:}

Robin E. Everts, Pascale Chavatte-Palmer, Anthony Razzak, Isabelle Hue, Cheryl A. Green, et al.. Aberrant gene expression patterns in placentomes are associated with phenotypically normal and abnormal cattle cloned by somatic cell nuclear transfer. Physiological Genomics, 2008, 33 (1), pp.6577. 10.1152/physiolgenomics.00223.2007 . hal-02667181

\section{HAL Id: hal-02667181 https://hal.inrae.fr/hal-02667181}

Submitted on 31 May 2020

HAL is a multi-disciplinary open access archive for the deposit and dissemination of scientific research documents, whether they are published or not. The documents may come from teaching and research institutions in France or abroad, or from public or private research centers.
L'archive ouverte pluridisciplinaire HAL, est destinée au dépôt et à la diffusion de documents scientifiques de niveau recherche, publiés ou non, émanant des établissements d'enseignement et de recherche français ou étrangers, des laboratoires publics ou privés. 
Robin E. Everts, Pascale Chavatte-Palmer, Anthony Razzak, Isabelle Hue, Cheryl A. Green, Rosane Oliveira, Xavier Vignon, Sandra L. Rodriguez-Zas, X. Cindy Tian, Xiangzhong Yang, Jean-Paul Renard and Harris A. Lewin

Physiol Genomics 33:65-77, 2008. First published Dec 18, 2007;

doi:10.1152/physiolgenomics.00223.2007

You might find this additional information useful...

Supplemental material for this article can be found at: http://physiolgenomics.physiology.org/cgi/content/full/00223.2007/DC1

This article cites 91 articles, 37 of which you can access free at: http://physiolgenomics.physiology.org/cgi/content/full/33/1/65\#BIBL

This article has been cited by 6 other HighWire hosted articles, the first 5 are:

Effect of the method of conception and embryo transfer procedure on mid-gestation placenta and fetal development in an IVF mouse model

L. Delle Piane, W. Lin, X. Liu, A. Donjacour, P. Minasi, A. Revelli, E. Maltepe and P. F. Rinaudo

Hum. Reprod., August 1, 2010; 25 (8): 2039-2046.

[Abstract] [Full Text] [PDF]

Terminal differentiation of goat mammary tissue during pregnancy requires the expression of genes involved in immune functions

F. Faucon, E. Rebours, C. Bevilacqua, J.-C. Helbling, J. Aubert, S. Makhzami, S. Dhorne-Pollet,

S. Robin and P. Martin

Physiol Genomics, December 30, 2009; 40 (1): 61-82.

[Abstract] [Full Text] [PDF]

Dissection of Genetic Factors Modulating Fetal Growth in Cattle Indicates a Substantial

Role of the Non-SMC Condensin I Complex, Subunit G (NCAPG) Gene

A. Eberlein, A. Takasuga, K. Setoguchi, R. Pfuhl, K. Flisikowski, R. Fries, N. Klopp, R.

Furbass, R. Weikard and C. Kuhn

Genetics, November 1, 2009; 183 (3): 951-964.

[Abstract] [Full Text] [PDF]

Gene expression profiles of bovine caruncular and intercaruncular endometrium at implantation

N. Mansouri-Attia, J. Aubert, P. Reinaud, C. Giraud-Delville, G. Taghouti, L. Galio, R. E.

Everts, S. Degrelle, C. Richard, I. Hue, X. Yang, X. C. Tian, H. A. Lewin, J.-P. Renard and O.

Sandra

Physiol Genomics, September 9, 2009; 39 (1): 14-27.

[Abstract] [Full Text] [PDF]

Endometrium as an early sensor of in vitro embryo manipulation technologies

N. Mansouri-Attia, O. Sandra, J. Aubert, S. Degrelle, R. E. Everts, C. Giraud-Delville, Y.

Heyman, L. Galio, I. Hue, X. Yang, X. C. Tian, H. A. Lewin and J.-P. Renard

PNAS, April 7, 2009; 106 (14): 5687-5692.

[Abstract] [Full Text] [PDF]

Updated information and services including high-resolution figures, can be found at:

http://physiolgenomics.physiology.org/cgi/content/full/33/1/65

Additional material and information about Physiological Genomics can be found at: http://www.the-aps.org/publications/pg

This information is current as of September 9, 2010 .

Physiological Genomics publishes results of a wide variety of studies from human and from informative model systems with techniques linking genes and pathways to physiology, from prokaryotes to eukaryotes. It is published quarterly in January, April, July, and October by the American Physiological Society, 9650 Rockville Pike, Bethesda MD 20814-3991. Copyright () 2008 by the American Physiological Society. ISSN: 1094-8341, ESSN: 1531-2267. Visit our website at http://www.the-aps.org/. 


\title{
Aberrant gene expression patterns in placentomes are associated
}

\section{with phenotypically normal and abnormal cattle cloned by somatic cell nuclear transfer}

\author{
Robin E. Everts, ${ }^{1}$ Pascale Chavatte-Palmer, ${ }^{2}$ Anthony Razzak, ${ }^{1}$ Isabelle Hue, ${ }^{2}$ Cheryl A. Green, ${ }^{1}$ \\ Rosane Oliveira, ${ }^{1}$ Xavier Vignon, ${ }^{2}$ Sandra L. Rodriguez-Zas, ${ }^{1}$ X. Cindy Tian, ${ }^{3}$ Xiangzhong Yang, ${ }^{3}$ \\ Jean-Paul Renard, ${ }^{2}$ and Harris A. Lewin ${ }^{1}$ \\ ${ }^{1}$ Department of Animal Sciences, University of Illinois at Urbana-Champaign, Urbana, Illinois; ${ }^{2}$ UMR Biologie \\ du Développement et Reproduction, Institut National de la Recherche Agronomique, Jouy-en-Josas, France; and ${ }^{3}$ Center \\ for Regenerative Biology/Department of Animal Sciences, University of Connecticut, Storrs, Connecticut
}

Submitted 25 September 2007; accepted in final form 11 December 2007

Everts RE, Chavatte-Palmer P, Razzak A, Hue I, Green CA, Oliveira R, Vignon X, Rodriguez-Zas SL, Tian XC, Yang X, Renard JP, Lewin HA. Aberrant gene expression patterns in placentomes are associated with phenotypically normal and abnormal cattle cloned by somatic cell nuclear transfer. Physiol Genomics 33: 65-77, 2008. First published December 18, 2007; doi:10.1152/physiolgenomics.00223.2007._Transcription profiling of placentomes derived from somatic cell nuclear transfer (SCNT, $n=$ 20 ), in vitro fertilization (IVF, $n=9$ ), and artificial insemination (AI, $n=9$ ) at or near term development was performed to better understand why SCNT and IVF often result in placental defects, hydrops, and large offspring syndrome (LOS). Multivariate analysis of variance was used to distinguish the effects of SCNT, IVF, and AI on gene expression, taking into account the effects of parturition (term or preterm), sex of fetus, breed of dam, breed of fetus, and pathological finding in the offspring (hydrops, normal, or other abnormalities). Differential expression of 20 physiologically important genes was confirmed with quantitative PCR. The largest effect on placentome gene expression was attributable to whether placentas were collected at term or preterm (i.e., whether the collection was because of disease or to obtain stage-matched controls) followed by placentome source (AI, IVF, or SCNT). Gene expression in SCNT placentomes was dramatically different from AI ( $n=336$ genes; $276>2$-fold) and from IVF ( $n=733$ genes; $162>2$-fold) placentomes. Functional analysis of differentially expressed genes (DEG) showed that IVF has significant effects on genes associated with cellular metabolism. In contrast, DEG associated with SCNT are involved in multiple pathways, including cell cycle, cell death, and gene expression. Many DEG were shared between the gene lists for IVF and SCNT comparisons, suggesting that common pathways are affected by the embryo culture methods used for IVF and SCNT. However, the many unique gene functions and pathways affected by SCNT suggest that cloned fetuses may be starved and accumulating toxic wastes due to placental insufficiency caused by reprogramming errors. Many of these genes are candidates for hydrops and LOS.

placenta; bovine; reprogramming

ALTHOUGH MAMMALIAN CLONING by somatic cell nuclear transfer (SCNT) has been practiced for the past 10 years (84), the cloning process remains largely inefficient because of losses during gestation $(12,63)$. For example, the cloning efficiency of transferred cattle embryos that develop through term is generally $<10 \%(27,44,90)$. Approximately $80 \%$ of trans-

Address for reprint requests and other correspondence: H. A. Lewin, Institute for Genomic Biology, Rm. 1608, 1206 W. Gregory Dr., Urbana, IL 61801. ferred cattle embryos are lost before the beginning of the second trimester $(5,44,49)$. The majority of failed pregnancies appear to result from abnormal placental development, such as reduced vascularization, and fewer but enlarged placentomes $(16,20,40,49,50)$. Recent evidence strongly links errors in reprogramming of the donor nucleus to the placental and fetal developmental anomalies of mammals cloned by SCNT (10, $11,52,54,55,59)$. A current hypothesis is that the extraembryonic tissues of the embryo fail to develop normally in SCNT clones, which causes subsequent abnormalities in implantation and development of the placenta $(20,34,49)$. Support for this hypothesis derives from the comparison of SCNT- to in vivo-derived bovine embryos, which revealed an altered ratio of inner cell mass (ICM) cells to trophectoderm cells (56). Aberrant gene expression in SCNT-derived extraembryonic tissues and fetuses has been confirmed from the morula stage until day 65 of gestation and seems to become more widespread during later pregnancy (6, 9, 40, 42, 68, 69, $74,75)$. However, the genes, timing, and duration of the genetic lesions that cause placental defects in SCNT-cloned cattle have not been determined.

Of those SCNT-derived embryos that develop to term, up to $40 \%$ have large offspring syndrome (LOS), which is characterized by enlarged organs, hydrops of the fetus, lethargy, and respiratory distress $(16,18,34,59,92)$. In all cases of LOS, the placenta is enlarged and edematous. It is noteworthy that LOS is also observed in offspring produced by in vitro fertilization (IVF) and has a human clinical correlate in Beckwith-Wiedemann syndrome, which is associated with imprinting defects (22). Although there are gross placental abnormalities of SCNT-cloned cattle, the general health of surviving offspring appears to be normal. For example, the health status and milk and meat production of cloned cattle surviving past the first year of life was similar to that of artificial insemination (AI)-derived animals $(17,45,47,79,82)$. In contrast, SCNTderived mice are obese (78) and have markedly shorter life spans (67). Apparently, for fetal survival the placenta must overcome and compensate for the developmental defects caused by reprogramming errors, and the cloned offspring also must adapt to these changes, which may result in fetal growth retardation $(2,37)$. The stochastic nature of placental development that occurs as a result of SCNT-induced genomic perturbations would be consistent with such observations.

Comparison of gene expression profiles of placentomes collected from SCNT pregnancies may provide important in- 
sights into the metabolic and cellular pathways that are affected by SCNT, the adaptations that are necessary for fetal survival, and the molecular defects underlying LOS. The design of the present study allowed us to address this issue by examination of gene expression patterns in placentomes collected from SCNT, IVF, and AI pregnancies. The occurrence of hydrops in $30 \%$ of the samples permitted an analysis of the genes and gene expression patterns underlying this condition. Results demonstrate gross abnormalities in placentome gene expression associated with SCNT cloning. Surprisingly, IVF also produced a large number of differences in placentome gene expression compared with AI and SCNT samples. Functional annotation of differentially expressed genes (DEG) and pathway analysis revealed multiple affected pathways in SCNT-cloned cattle that may contribute to the development of LOS and hydrops.

\section{MATERIALS AND METHODS}

Recipients and calves. Recipient animals for IVF- or SCNTderived embryos were normal cycling heifers located at the Institut National de la Recherche Agronomique (INRA) experimental farms in Bourges $(n=4)$ and Bressonvillier $(n=34)$, France. The heifers were subjected to estrous synchronization with a progesterone-releasing intravaginal device (Crestar-Intervet, Angers, France). A separate control group of heifers was artificially inseminated with either Holstein or Charolais bull semen at 48 and $60 \mathrm{~h}$ after administration of prostaglandin $\left(\mathrm{PGF}_{2 \alpha}\right)$.

The SCNT calves were produced by transfer of nuclei from two adult skin fibroblast cell cultures (5538 and 7711) and one fetal fibroblast cell culture (BSF204), as previously described (16, 18, 46, 79a). IVF embryos were cultured in sequential media without fetal bovine serum or oviduct cells, whereas SCNT embryos were cocultured with oviduct cells $(16,18)$. For both IVF and SCNT, embryos of quality grade 1 were transferred to synchronized recipients after 7 days of culture.

The experiments were performed in accordance with the International Guiding Principles for Biomedical Research Involving Animals, as promulgated by the Society for the Study of Reproduction, and with the European Convention on Animal Experimentation. Research work on cloned animals was approved by the INRA ethics committee (Ethical and Precaution Committee for Agronomical Research Application) in December 1999 as well as by the Comité Scientifique des Utilisateurs (IACUC) of INRA.

Collection of placentomes and RNA isolation. Several of the placentome samples used in the present study were included in the morphometric analysis as described by Constant and coworkers (18), and all samples were collected with the same protocol. The placentome sampling procedure produced relatively consistent sampling of fetal and maternal tissues $(\sim 42 \%$ fetal, $58 \%$ maternal in AI samples and $\sim 47 \%$ fetal, $53 \%$ maternal in SCNT samples). Briefly, one placentome from the pregnant uterine horn was sampled (1-2 g), using care to harvest from the same area for all placentome samples. The tissue sample was flash frozen in liquid nitrogen and stored at $-80^{\circ} \mathrm{C}$ until RNA extraction. Calves were classified as normal or hydrops, based on the absence or presence of edema in the animal and/or placental tissues. A more detailed description of the diagnosis of hydrops can be found elsewhere $(14,18)$. Preterm calves were between day 174 and day 260 of gestation; term calves were delivered at 260 days or later. RNA was isolated from the placentome samples with TRIzol reagent (Invitrogen, Carlsbad, CA). Quality and integrity of RNA were assessed by spectrophotometry and denaturing agarose gel electrophoresis. The resulting RNA was resuspended in doubledistilled $\mathrm{H}_{2} \mathrm{O}$ with $20 \mathrm{mM}$ DTT and $40 \mathrm{U}$ of RNasin (Invitrogen) and stored at $-80^{\circ} \mathrm{C}$ until use.

Microarrays, RNA labeling, and hybridization. A 13,257-element bovine oligoarray [NCBI Gene Expression Omnibus (GEO): GPL2853] was used for transcript profiling (61). The oligonucleotides were selected from expressed sequence tags (ESTs) obtained from a placenta and spleen cDNA library (30) and cDNA libraries created from a mix of a day 36 fetus, a day 64 fetus, and extraembryonic tissues from days 14-25 (NCBI Libraries 15575, 15980, 15992, 15993, and 17811) and from endometrial tissues (NCBI Library 16609). The annotation for each selected sequence was updated with human UniGene (build 201), mouse UniGene (build 162), and bovine UniGene (build 83) databases. Ten micrograms of sample and reference RNA was used to make aminoallyl-labeled cDNA followed by incorporation of Cy3-ester or Cy5-ester (Amersham, Piscataway, $\mathrm{NJ}$ ) essentially as described previously (60). The samples were then combined, denatured, and cohybridized on the 13,257 oligoarray at $42^{\circ} \mathrm{C}$ for $40 \mathrm{~h}$. After stringency washes to remove unbound cDNA, the oligoarrays were scanned with an Axon 4000B scanning densitometer (Molecular Devices, Sunnyvale, CA) and images were processed with GenePix 4.0 software (Molecular Devices). Scanning normalization of the data was accomplished by using the automated global normalization feature of GenePix 6.0. Microarray data are MIAME compliant and deposited in the NCBI GEO database (www.ncbi.nlm.nih.gov/geo; accession number GSE8923).

Data analysis. First the local background intensity was subtracted from the foreground (signal) intensity, and only spots with median signal intensity greater than the median intensity of the negative control spots for either one of the dyes ( $\mathrm{Cy} 5$ or $\mathrm{Cy} 3)$ were considered "expressed." For each dye, signal intensities for spots with median signal intensity lower than the median background intensity for that spot were set to 1 . The resulting output files were loaded into GeneSpring 7.3.1, and the data for hierarchical clustering were normalized with LOESS regression.

A mixed-effects model using SAS software's (73) Proc MIXED (86), employing the aforementioned median negative control spot cutoff strategy, was used to determine gene expression differences. First, $\log _{2}$-transformed ratios of signal intensity for placentome divided by the reference were normalized for dye and array effects with LOESS regression and array centering. Then a first-stage model fit the normalized $\log _{2}$-transformed ratio across all genes for the effects of dye and array. The residuals were then analyzed by gene in a second-stage model that included the fixed effects of placentome type (AI, SCNT, or IVF), duration of pregnancy, breed of fetus, breed of dam, phenotype, sex, and dye and the random effect of dye and animal. Cell line (used for SCNT) effects were also tested in preliminary analysis but were removed from the final model because the effects were confounded by sample size. Statistically significant $P$ values for the models were adjusted for multiple comparisons with the false discovery rate (FDR) approach (4). For all analyses, an FDRadjusted $P$ value $<0.3$, corresponding to a raw $P$ value of $\sim 10^{-3}$ $10^{-4}$, and a minimum of 18 degrees of freedom were used as a significance threshold. Unless otherwise noted, ratios used in this paper are the adjusted ratios as derived from the statistical model. To facilitate data mining, MetaCore (GeneGO, http://trials.genego.com; version 4.3, build 9787) and Ingenuity Pathway Analysis (IPA; http://www.ingenuity.com; release 5.1, 7/8/2007) were used to analyze the DEG and to identify significant Bio Functions and canonical pathways associated with specific lists of DEG. Only IPA Bio Functions having $P<0.05$ and at least five DEG were used for further analysis. For the analysis of canonical pathways in IPA, only pathways with $P \leq 0.05$ and having three or more DEG were considered as biologically relevant.

Quantitative PCR. Primers were designed to specifically amplify 21 target genes and an endogenous control gene, beta-actin (ACTB), with Primer Express Software v2.0 (Applied Biosystems, Foster City, $\mathrm{CA}$ ). The sequences, product sizes, and accession numbers are listed in Supplemental Table S19. ${ }^{1}$ Purification of total RNA and RT-PCR

\footnotetext{
${ }^{1}$ The online version of this article contains supplemental material.
} 
were carried out as described elsewhere (60). cDNA synthesis was performed in duplicate. Quantitative PCR (qPCR) was done with an ABI Prism 7900HT SDS instrument as described previously (60). Relative quantification of mRNA amounts of the target genes was calculated according to the relative standard curve method (60). Duplicate data were pooled, and the mixed model as described above was run on the qPCR values to assess the differential expression. Genes were considered differentially expressed if the mixed model $P$ value was $\leq 0.05$.

\section{RESULTS}

Overview of analysis. Gene expression profiles of placentomes collected from AI $(n=9), \operatorname{IVF}(n=9)$, and SCNT $(n=$ 20) pregnancies were obtained by hybridization of placentome cDNAs to oligonucleotide microarrays specific for $\sim 13,000$ unique cattle genes. A reference design with dye swap was used for the experiment (76 microarrays total). A total of 12,787 oligonucleotide probes gave signals above the threshold level for expression. Patterns in gene expression among the samples were analyzed by hierarchical clustering of normalized ratios, and multivariate analysis of variance (MANOVA) was used to detect differences in the expression of individual genes according to placentome source (AI, IVF, and SCNT), taking into account the effects of sex of fetus, length of pregnancy, breed of dam, breed of fetus, and fetal pathology. The MANOVA detected 1,747 DEG attributable to all variables in the model. A FDR of 0.30 was used for all contrasts to maximize the sensitivity to detect gene function categories, pathways, and networks affected by each of the variables. qPCR was used to confirm the microarray results and to provide additional support for the functional analysis of DEG.
The results of cluster analysis, MANOVA, qPCR, and functional analysis of DEG are summarized below.

Cluster analysis reveals distinct groupings on the basis of placentome source. Hierarchical clustering of the normalized expression ratios of all 12,787 expressed genes relative to the reference sample revealed four major groupings (Fig. 1). The correlation between all sample clusters is 0.62 , demonstrating a high degree of similarity in expression profiles among the samples (Fig. 1). Within the four major clusters identified, correlation ranged from 0.70 to 0.86 . Cluster I contains four of five term AI samples, all of which were phenotypically normal. Cluster II contains six of eight preterm samples (2 SCNT, 3 AI, and 1 IVF). This cluster also contains four of six hydrops samples. Cluster III, the largest, contains most of the phenotypically normal SCNT (7 of 11) and IVF (6 of 8) samples. Cluster IV, the smallest, contains three phenotypically normal SCNT samples and the remaining two AI samples, of which one was preterm. There were two SCNT samples, one phenotypically normal and one preterm with hydrops, that clustered with each other but independently of all other samples. The attributes of the samples within the clusters suggest that placentome source, duration of pregnancy, and fetal pathology account for most of the variation in gene expression. However, the compound groupings indicate that multiple sources of variation contribute to the general patterns in gene expression, thus indicating the importance of MANOVA for discerning the effects of each variable on gene expression among the placentome samples.

Effect of AI, IVF, and SCNT (source) on gene expression in placentomes. To exclude the possibility of biased tissue sampling, we first examined a subset of genes present on the

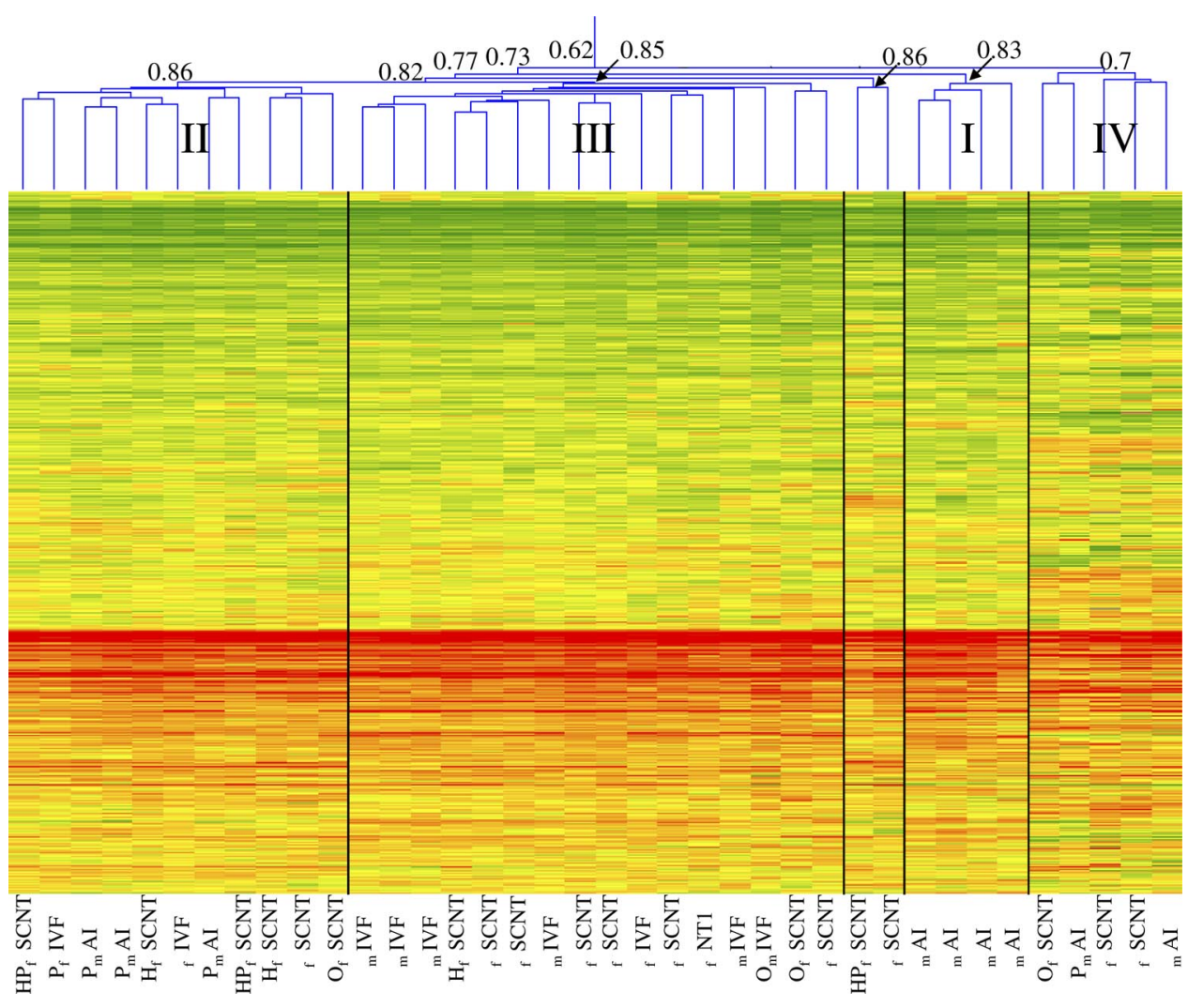

Physiol Genomics • VOL 33 • www.physiolgenomics.org
Fig. 1. Cluster diagram of all 38 gene expression profiles based on 12,787 expressed genes. Each column represents the combined data of 2 arrays for an animal, whereas each line represents a specific gene. The clusters are indicated with Roman numerals (as discussed in the text). Pearson correlations $(r)$ for major branches are shown. Red indicates high expression in the placentome samples, whereas green indicates low expression in the placentome samples compared with the reference sample. Sample source: artificial insemination (AI), in vitro fertilization (IVF), and somatic cell nuclear transfer (SCNT). Sex: m, male; f, female. All samples are normal term placentomes unless noted otherwise with the following symbols: P, preterm; H, hydrops; O, other phenotype. 
microarray and known to be expressed exclusively in fetal derived ( $n=15$ genes) or maternal derived ( $n=3$ genes) placental tissue (76). Correlations of expression ratios for known maternal and fetal expressed genes both within the three sample sources $(r>0.88)$ and between sample sources $(r>$ 0.88 ) show that the relative proportion of maternal and fetal tissues in the placentome samples was generally consistent (Supplemental Table S1). Thus tissue sampling was unlikely to be a significant source of variation in gene expression.

Among the 1,747 DEG detected by MANOVA, 956 were attributed to sample source (AI, IVF, and SCNT; Table 1, Fig. 2; Supplemental Tables S2-S4). For the three pairwise group comparisons of DEG (AI-SCNT, AI-IVF, and IVF-SCNT), the largest number of differences were detected between SCNT and IVF ( $n=733 ; 162>2$-fold), followed by SCNT and AI ( $n=336 ; 276>2$-fold). Expression differences for relatively few genes $(n=66)$ were found for the AI-IVF comparison. A Venn diagram of DEG for each of the pairwise group comparisons permitted the identification of DEG unique and overlapping for each comparison (Fig. 2). The comparison with the largest number of unique DEG was SCNT-IVF $(n=593)$, followed by SCNT-AI $(n=186)$, and AI-IVF $(n=22)$. These results demonstrate that the SCNT samples are the outlier in their gene expression profile. Only four genes (BCKDHB, ECT2, KIAA1333, WDR61) were differentially expressed in all three pairwise comparisons. These four genes were expressed at the lowest level in SCNT and highest in AI placentomes. Among the 37 genes putatively imprinted in cattle that are represented on the microarray, the expression levels of CPA4, COMMDI, and GRB10 were affected by placentome source; all were in comparisons involving IVF samples (Supplemental Tables S3 and S4).

An analysis of the distribution of DEG in IPA Bio Function categories was performed to gain insight into the cellular functions, biochemical processes, and disease-related genes that were affected by placentome source (Supplemental Tables S5-S7). All frequency comparisons were based on the number of genes associated to each IPA term for the genes on the microarray (not the total number of genes associated to each term in the Ingenuity Pathway Knowledge Database). A comparison of the 336 DEG in the SCNT-AI comparison revealed significant associations $(P<0.05)$ for 40 terms having $\geq 5$ genes, including DNA replication, recombination and repair,

Table 1. Results of MANOVA

\begin{tabular}{llcc}
\hline \hline \multicolumn{1}{c}{ Variable } & \multicolumn{1}{c}{ Terms } & $\begin{array}{c}\text { No. Genes } \\
\text { (FDR } P<0.3) *\end{array}$ & $\begin{array}{c}\text { No. }>2 \text {-Fold } \\
\text { Different }\end{array}$ \\
\hline Placentome source & AI, IVF, SCNT & 956 & 420 \\
AI vs. SCNT & & 336 & 276 \\
AI vs. IVF & & 66 & 50 \\
IVF vs. SCNT & & 733 & 162 \\
Duration of pregnancy & Term, preterm & 873 & 112 \\
Breed of dam & HF, CH, NM, C & 76 & 35 \\
Breed of fetus & HF, CH & 1 & 1 \\
Phenotype & Hydrops, normal & 17 & 7 \\
Sex & Male, female & 83 & 38 \\
\hline
\end{tabular}

MANOVA, multivariate analysis of variance; FDR, false discovery rate; AI, artificial insemination; IVF, in vitro fertilization; SCNT, somatic cell nuclear transfer; HF, Holstein-Friesian; CH, Charolais; NM, Normande; C, crossbred. *No. of differentially expressed genes (DEG) exceeds 1,747 because of overlap between categories.

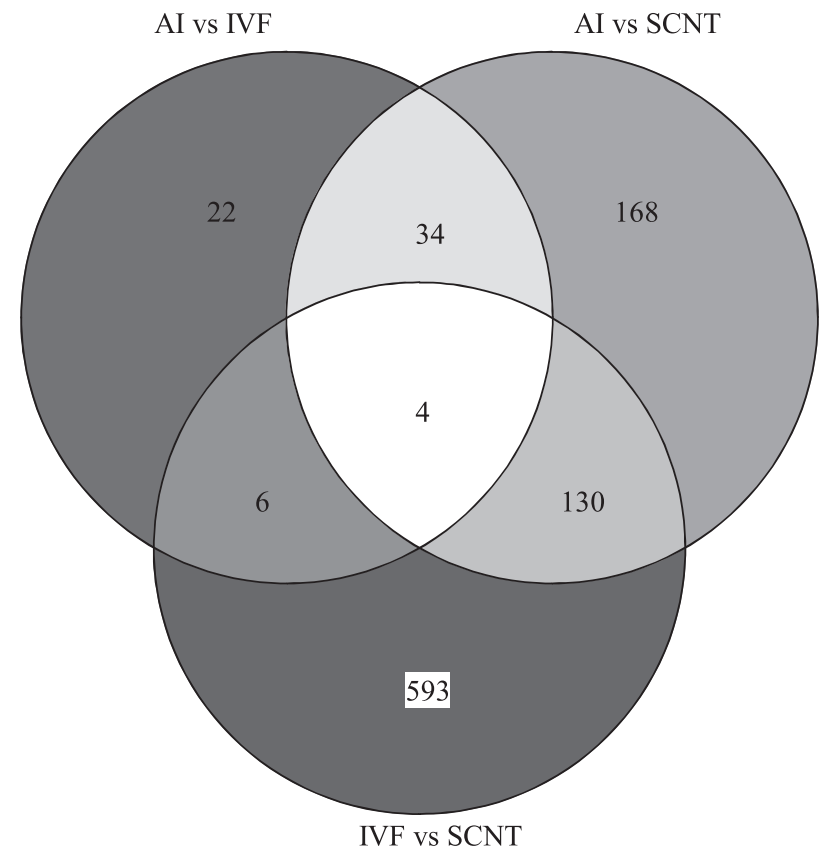

Fig. 2. Overlap of the differentially expressed genes (DEG) for the 3 placentome sources. Each circle represents a pairwise comparison of DEG from among 12,787 expressed genes.

cell cycle, cell death, RNA posttranslational modification, gene expression, protein trafficking, cell-to-cell signaling and interaction, molecular transport, cancer, cell morphology, connective tissue development, cellular growth and proliferation, and reproductive system disease (Table 2, Supplemental Table S5). Canonical pathways affected in the SCNT-AI comparison include oxidative phosphorylation (7 genes), cell cycle: $G_{2} / M$ DNA damage checkpoint regulation (3 genes), and purine metabolism (11 genes) (Supplemental Table S6).

For the SCNT-IVF comparison, 57 IPA Bio Function terms with five or more genes showed significant associations $(P<$ 0.05; Supplemental Table S7). There is overlap of 35 of 40 terms with the SCNT-AI list and 22 terms that are unique to the SCNT-IVF comparison. Additional terms include several associated with metabolism (e.g., lipid metabolism, carbohydrate metabolism, amino acid metabolism), with growth, tissue and organ development, and many different diseases. Ten canonical pathways with three or more genes were significantly affected, including hypoxia signaling in the cardiovascular system (11 genes), oxidative phosphorylation (12 genes), purine metabolism (21 genes), PI3/AKT signaling (13 genes), and TGF- $\beta$ signaling (11 genes) (Supplemental Table S8).

In contrast to the two pairwise comparisons involving SCNT samples, comparison of AI to IVF samples identified only four significantly affected IPA Bio Function/disease categories: cancer, carbohydrate metabolism, small molecule biochemistry, and cellular growth and proliferation (Supplemental Table S9). The only canonical pathway with three or more DEG affected was oxidative phosphorylation $(P<0.05$; Supplemental Table S10). The main effects of IVF on placentome gene expression thus appear to be on cellular metabolism.

Effect of hydrops on gene expression in placentomes. Among the SCNT pregnancies, 30\% (6 of 18) of the fetuses showed evidence of hydrops (all hydrallantois). By MANOVA, 
Table 2. Most significant $(P<0.01)$ IPA Bio Function categories and DEG within categories for the comparison of AI and SCNT placentomes

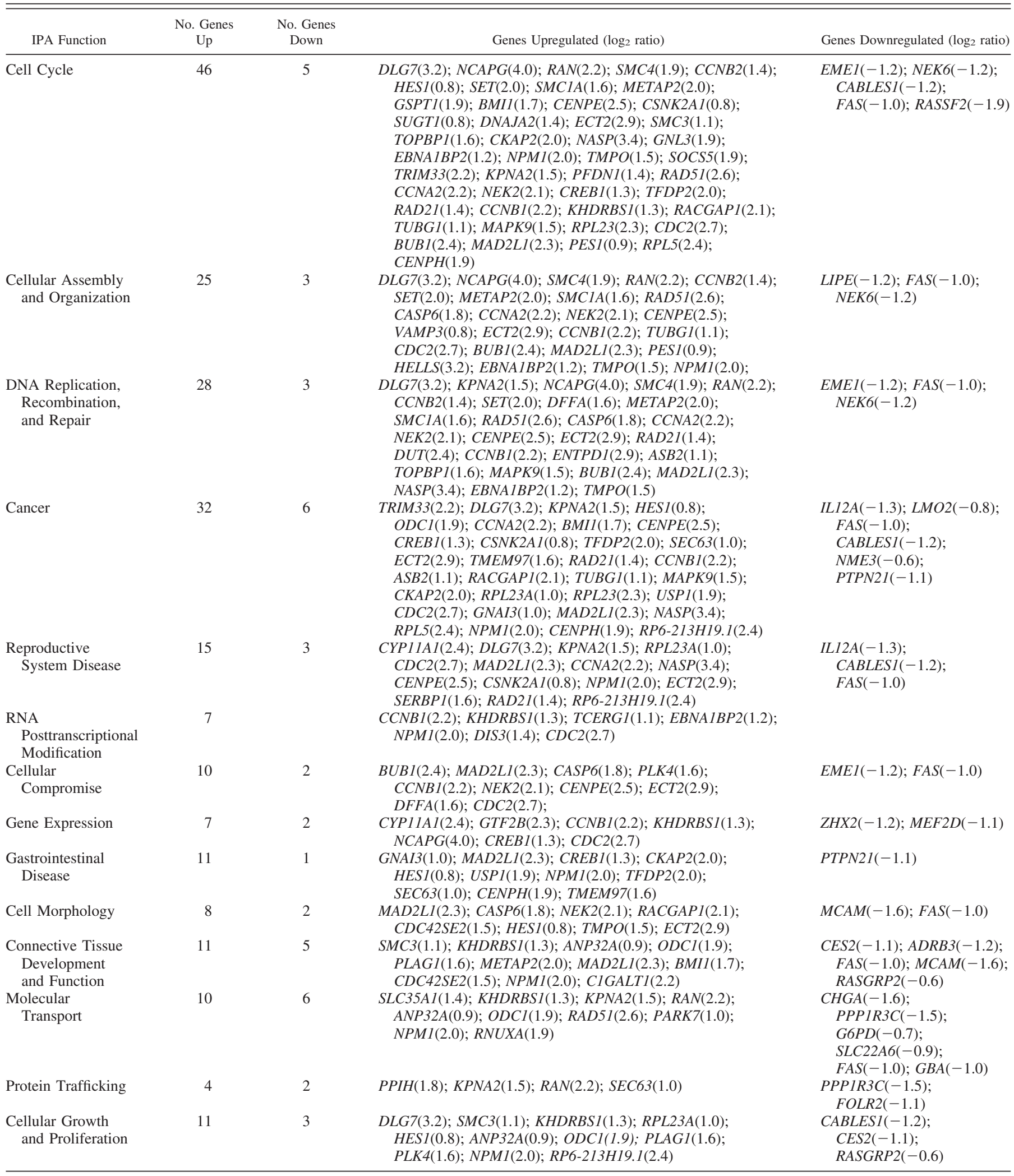


Table 2.-Continued

\begin{tabular}{|c|c|c|c|c|}
\hline IPA Function & $\begin{array}{l}\text { No. Genes } \\
\text { Up }\end{array}$ & $\begin{array}{l}\text { No. Genes } \\
\text { Down }\end{array}$ & Genes Upregulated ( $\log _{2}$ ratio) & Genes Downregulated ( $\log _{2}$ ratio) \\
\hline $\begin{array}{l}\text { Amino Acid } \\
\text { Metabolism }\end{array}$ & 13 & 5 & $\begin{array}{l}C C N B 1(2.2) ; \operatorname{HATl}(2.7) ; \operatorname{MAPK} 9(1.5) ; \operatorname{COL} 4 A 3 B P(2.6) ; \\
\text { CDC2(2.7); DYRK3(1.6); SRP72(1.2); VRK1(1.9); } \\
\text { PLK4(1.6); ASRGL1(1.3); CSNK2A1(0.8); SGK3(2.7); RP6- } \\
\text { 213H19.1(2.4) }\end{array}$ & $\begin{array}{l}\operatorname{LIPE}(-1.2) ; G B A(-1.0) \\
\quad \text { NEK6 }(-1.2) \\
\quad P T P N 21(-1.1) \\
\quad P D K 4(-3.7)\end{array}$ \\
\hline $\begin{array}{l}\text { Posttranslational } \\
\text { Modification }\end{array}$ & 17 & 5 & $\begin{array}{l}\text { HUWE1(2.7); CCNB1(2.2); HAT1(2.7); UBE2D2(1.2); } \\
\text { MAPK9(1.5); COLAA3BP(2.6); SET(2.0); CDC2(2.7); } \\
\text { DYRK3(1.6); SRP72(1.2); VRK1(1.9); CASP6(1.8); } \\
\text { PLK4(1.6); BMI1(1.7); CSNK2A1(0.8); SGK3(2.7); RP6- } \\
\text { 213H19.1(2.4) }\end{array}$ & $\begin{array}{l}\operatorname{LIPE}(-1.2) ; \operatorname{NEK} 6(-1.2) \\
\quad \operatorname{IMMP} 2 L(-1.1) \\
\quad P T P N 21(-1.1) \\
\quad P D K 4(-3.7)\end{array}$ \\
\hline $\begin{array}{r}\text { Small Molecule } \\
\text { Biochemistry }\end{array}$ & 22 & 14 & $\begin{array}{l}\text { SQLE(2.4); SLC35A1(1.4); ODC1(1.9); DYRK3(1.6); } \\
\text { VRK1(1.9); SRP72(1.2); PLK4(1.6); PARK7(1.0); } \\
\text { CSNK2A1(0.8); OXCT1(1.7); CYP11A1(2.4);CCNB1(2.2); } \\
\text { ENTPD1(2.9); HAT1(2.7); MAPK9(1.5); COL4A3BP(2.6); } \\
\text { CDC2(2.7); PPA1(1.6); GNAI3(1.0); APLN(2.3); } \\
\text { SGK3(2.7); RP6-213H19.1(2.4) }\end{array}$ & $\begin{array}{l}\text { PPPIR3C }(-1.5) ; \\
\text { LIPE }(-1.2) ; \text { CES2 }(-1.1) ; \\
\text { ADRB3 }(-1.2) ; \text { FAS }(-1.0) ; \\
\text { GBA }(-1.0) ; \text { NEK6 }(-1.2) ; \\
\text { PDK4 }(-3.7) ; \\
\text { CHGA }(-1.6) ; \\
\text { G6PD }(-0.7) ; \\
\text { CMAH }(-1.2) ; \\
\text { EMR } 2(-1.1) ; \\
\text { CHIA }(-1.5) ; \\
\text { PTPN21(-1.1) }\end{array}$ \\
\hline $\begin{array}{l}\text { Cell-to-Cell } \\
\text { Signaling and } \\
\text { Interaction }\end{array}$ & 6 & 2 & $\begin{array}{l}\text { SMC3(1.1); HES1(0.8);C1GALT1(2.2); ANP32A(0.9); } \\
\quad \text { METAP2(2.0); PLAG1(1.6) }\end{array}$ & $\operatorname{EMR} 2(-1.1) ; F A S(-1.0)$ \\
\hline $\begin{array}{l}\text { Cellular Function } \\
\text { and Maintenance }\end{array}$ & 13 & 3 & $\begin{array}{l}\text { SMC3(1.1); TRIM33(2.2); ASB2(1.1); RACGAP1(2.1); } \\
\quad \text { ANP32A(0.9); CDC2(2.7); PLAG1(1.6); METAP2(2.0); } \\
\text { GNAI3(1.0); NEK2(2.1); CSNK2A1(0.8);VAMP3(0.8); } \\
\text { NPM1(2.0) }\end{array}$ & $\begin{array}{l}\operatorname{LIPE}(-1.2) ; F A S(-1.0) \\
\quad N M E 3(-0.6)\end{array}$ \\
\hline $\begin{array}{l}\text { Skeletal and } \\
\text { Muscular } \\
\text { Disorders }\end{array}$ & 7 & & $\begin{array}{l}\text { CCNA2(2.2); RPL5(2.4); RPL23(2.3); NPM1(2.0); } \\
\quad \text { PAPSS2(2.2); CDC2(2.7); LBR(1.9); }\end{array}$ & \\
\hline Lipid Metabolism & 4 & 4 & CYP11A1(2.4); GNAI3(1.0); BDH2(1.2); OXCT1(1.7) & $\begin{array}{l}G B A(-1.0) ; \operatorname{LIPE}(-1.2) \\
\quad A D R B 3(-1.2) ; \operatorname{FAS}(-1.0)\end{array}$ \\
\hline
\end{tabular}

Ratios are given as $\log _{2}$ fold changes of AI compared with SCNT samples. IPA, Ingenuity Pathway Analysis.

17 DEG associated with hydrops were detected (Table 3). Although the small number of DEG precluded a robust analysis of functions affected specifically by hydrops, functional annotations for 14 of 17 DEG were available. These include the downregulated genes ( $>3$-fold in hydrops) GREB1, an estrogen-responsive gene involved in control of cell proliferation,

Table 3. Genes differentially expressed in hydrops and normal SCNT placentomes $(F D R P<0.30)$

\begin{tabular}{lcc}
\hline \hline Gene Symbol & Ratio & NCBI Gene ID \\
\hline ABLIM2 & 0.6 & 84448 \\
ANKRD29 & 1.5 & 147463 \\
COL4A3BP & 2.5 & 10087 \\
GREB1 & 0.3 & 9687 \\
GRSF1 & 2.5 & 2926 \\
JOSD1 & 2.0 & 9929 \\
KLF11 & 2.1 & 8462 \\
LOC614899 & 0.7 & 614899 \\
PRKAR2A & 1.7 & 19087 \\
TCRG & 0.3 & 6965 \\
TMPIT & 2.5 & 83862 \\
TXNDC12 & 2.5 & 51060 \\
USP6NL & 1.9 & 9712 \\
OLIGO_00241* & 0.7 & Bt.33247 \\
OLIGO_01814* & 1.4 & Hs.661988 \\
OLIGO_04290* & 0.7 & None \\
OLIGO_09660* & 0.6 & Bt.45678 \\
\hline
\end{tabular}

Ratios are given as hydrops over normal samples. *Oligo IDs are given for DEG without any gene annotation. and $T C R G$, which encodes the gamma chain of the T-cell receptor for antigen. Genes that were overexpressed ( $>2$-fold) in hydrops relative to normal placentomes included GRSF1, which encodes a G-rich RNA sequence binding factor-associated morphogenesis of embryonic epithelium, KLF11, which encodes a zinc-finger protein involved in negative regulation of cell growth and proliferation, and TXNDC12 (confirmed by qPCR, Table 4), a thioredoxin domain-containing protein involved in defense against oxidative stress. Notably, the transcript encoding PRKAR2A, a regulatory $\alpha$-subunit of a cAMPdependent protein kinase, was also upregulated. PRKAR2A is known to undergo dramatic changes in expression in human myometrium during gestation and parturition (62). Among the 17 hydrops-associated DEG, 16 (94\%) overlapped with DEG identified in the AI-SCNT comparison, thus indicating relatedness in the placentome gene expression patterns attributable to both SCNT and hydrops.

Effect of pregnancy duration (term, preterm) on placentome gene expression. Among the variables in the MANOVA, "duration of pregnancy" had the largest effect on gene expression other than placentome source, with 873 genes differentially expressed, of which 112 were more than twofold different (Supplemental Table S11). The majority of genes that were differentially expressed were upregulated in term compared with preterm samples. Among the genes with the largest differences in expression were PTGS2 (20-fold increase), IGFBP1 (10-fold increase), CYP19A1 (4-fold increase), SOD2 (4-fold 
Table 4. Results of confirmatory qPCR on selected genes

\begin{tabular}{|c|c|c|c|c|}
\hline Gene & GenBank ID & Comparison & $\begin{array}{l}\text { Microarray Fold } \\
\text { Change* }\end{array}$ & $\begin{array}{c}\text { TaqMan Fold } \\
\text { Change } \dagger\end{array}$ \\
\hline APRIN & BF043498 & AI vs. SCNT & 2.6 & 3.3 \\
\hline C6ORF204 & ВM365636 & Preterm vs. term & 0.4 & 0.2 \\
\hline CASPG & BF040727 & AI vs. SCNT & 3.5 & 4.0 \\
\hline$C D C 2$ & L26547 & AI vs. SCNT & 6.0 & 13.7 \\
\hline$C D C 2$ & L26547 & IVF vs. SCNT & 2.2 & 5.6 \\
\hline$C D C 2$ & L26547 & Hydrops vs. normal & 1.8 & 2.6 \\
\hline CSH1 & AW465564 & AI vs. SCNT & 9.9 & $2.3 \ddagger$ \\
\hline $\mathrm{CSH} 1$ & AW465564 & Preterm vs. term & 0.3 & 0.6 \\
\hline CSPG6 & BF040906 & AI vs. SCNT & 2.2 & 4.2 \\
\hline CYP19A1 & BF041489 & Preterm vs. term & 0.2 & 0.2 \\
\hline EBAG9 & BF042900 & AI vs. SCNT & 2.4 & 5.7 \\
\hline FAS & U34794 & AI vs. SCNT & 0.5 & $2.0 \S$ \\
\hline$G A P V D 1$ & AW465643 & AI vs. SCNT & 3.8 & 6.0 \\
\hline$G A P V D 1$ & AW465643 & AI vs. IVF & 2.7 & 2.4 \\
\hline$G L U L$ & AW465870 & Preterm vs. term & 0.5 & 0.5 \\
\hline HAT1 & AW464112 & AI vs. SCNT & 6.5 & 12.4 \\
\hline HES1 & AW465398 & AI vs. SCNT & 1.7 & 3.5 \\
\hline$L B R$ & CN440990 & AI vs. SCNT & 3.8 & 6.3 \\
\hline$N C A P G$ & CN435656 & AI vs. SCNT & 16.4 & 104.1 \\
\hline$N C A P G$ & CN435656 & IVF vs. SCNT & 3.1 & 10.8 \\
\hline$P D P N$ & AW461783 & Preterm vs. term & 0.4 & 0.4 \\
\hline PTGS2 & AW462092 & Preterm vs. term & 0.1 & 0.1 \\
\hline RAD51 & CR452998 & AI vs. SCNT & 6.3 & 18.1 \\
\hline RAD51 & CR452998 & IVF vs. SCNT & 2.0 & 4.7 \\
\hline SLC $30 A 4$ & BF040441 & Preterm vs. term & 0.3 & 0.5 \\
\hline TXNDC12 & BF046280 & Hydrops vs. normal & 2.5 & 1.6 \\
\hline$X L K D 1$ & BF041814 & Preterm vs. term & 0.5 & 0.4 \\
\hline
\end{tabular}

qPCR, quantitative PCR. *Gene significant at FDR $P<0.3$ on microarray; $\dagger$ tgene significant at $P<0.05$ by qPCR unless otherwise noted; †gene significant at $P<0.10$ by qPCR. The statistical model was the same for qPCR and microarray analyses, §not significant.

increase), CSH1 (PL in cattle; 3-fold increase), TCRG (6-fold decrease), $C Y P 4 F 2$ (3-fold decrease), CD19 (2-fold decrease), $H G F$ (2-fold decrease), and SLC1A6 (2-fold decrease). A very large number of IPA Bio Function terms ( $n=63$; Supplemental Table S12) were significantly associated to genes affected by duration of pregnancy, including (in order of highest significance, all $P<0.001)$ cell death, cell cycle, connective tissue development, cell signaling, and embryonic development. Canonical pathways affected included cell cycle: $G_{2} / M$ DNA damage checkpoint regulation and several related to signaling (neutrophin/Trk signaling, SAPK/JNK signaling, FGF signaling, and integrin signaling) and metabolism (sulfur, nitrogen, and inositol phosphate metabolism) (Supplemental Table S13). These results indicate major effects on functions related to cellular stress responses. The levels of expression of five imprinted genes, CPA4, GNAS, KCNQ1, MEG3, and NAP1L4, were also affected by duration of pregnancy. CPA4 and $G N A S$ were expressed at a higher level, whereas $K C N Q 1$, $M E G 3$, and NAPILA were expressed at a lower level in term placentomes.

Effect of fetal sex on placentome gene expression. Sex of the fetus had a significant effect on placentome gene expression (Supplemental Table S14). Among the 83 sex-related DEG, 9 were expressed at higher levels in male-bearing pregnancies, the remainder being expressed at higher levels in femalebearing pregnancies. The IPA terms significantly associated with the DEG included cell cycle, cellular assembly and organization, and cell morphology (Supplemental Table S15). No canonical pathways with three or more DEG were significantly affected by sex of the offspring.
qPCR analysis of selected genes. Twenty-one genes were picked to confirm the differences in gene expression detected with microarrays. The genes were picked on the basis of differences in placentome gene expression that were attributed to placentome source, hydrops, or duration of pregnancy. A total of 26 comparisons were made for the 21 genes; only one gene (FAS; AI-SCNT comparison) was not confirmed by qPCR (Table 4).

\section{DISCUSSION}

The gene expression profiles of AI, IVF, and SCNT placental biopsies were compared to elucidate the genes, pathways, and networks that produce placental defects, hydrops, and LOS. Furthermore, we aimed to gain insights into the genes and pathways that are affected by early reprogramming errors that occur during the SCNT process. Adjusting for all effects, the model detected 1,747 DEG (Table 1), of which most were attributed to placentome source and duration of pregnancy (term or preterm). By analyzing the expression of several genes reported to be expressed primarily in fetal or maternal tissue (76), we excluded the possibility that gene expression differences between AI, IVF, and SCNT placentomes were due to biased tissue sampling. qPCR was used to confirm key genes in specific pathways in order to substantiate conclusions drawn from the analysis. Expression differences were confirmed for 20 of 21 selected genes in 25 of 26 comparisons tested (Table 4).

Genes and pathways affected by in vitro maturation, fertilization, and culture: relation to LOS. The IVF procedure in cattle involves in vitro oocyte maturation and fertilization, embryo culture to the blastocyst stage (typically 7 days), and transfer to a synchronized recipient in diestrus. Similarly, SCNT involves all of the above except for IVF. Recently a number of abnormalities similar to LOS have been associated with mouse and human IVF, such as increased anaerobic glycolysis (35), loss of imprinting $(22,25)$, increased incidence of retinoblastoma (64), Beckwith-Wiedemann syndrome (22), and altered behaviors and spatial memory $(26,33)$. It has been hypothesized that the embryo culture procedures, particularly the use of serum that contains hormones and growth factors, cause the dysregulation of gene expression and imprinting (81, 91). Furthermore, cattle IVF (unlike that in humans) employs oocyte maturation in vitro, which also appears to have a dramatic effect on gene expression patterns in the developing embryo (74). In the human diseases Beckwith-Wiedemann and Angelman syndromes, both with a phenotype similar to LOS, loss of imprinting appears to play a major role in disease development $(23,38)$. Using microarray analysis, we (74) and others (36) have shown large numbers of DEG in cultured IVF blastocysts compared with those produced by AI, providing further evidence for a "culture effect" on gene expression in embryos. Thus a central question is to what extent differences in gene expression in cultured embryos are compensatory for the culture environment and result in normal offspring, or whether such compensatory changes may lead to developmental abnormalities.

To address this question, we compared gene expression in IVF and AI placentomes and found 66 DEG, of which 50 (76\%) were more than twofold different. Caution should be used in interpreting results on the basis of the smaller number of DEG (as compared with the IVF-SCNT comparison) be- 
cause of the reduced statistical power of the comparison resulting from a smaller number of $\mathrm{AI}(n=9)$ and $\operatorname{IVF}(n=$ 9) samples relative to the number of SCNT samples $(n=20)$. Still, cluster analysis showed that IVF placentomes have distinctly different expression profiles relative to AI (Fig. 1). These results suggest a significant and long-lasting effect of the cattle IVF procedure on placentome gene expression patterns. Many DEG are likely due to in vitro embryo culture, while others may be due to oocyte maturation and fertilization in vitro (see further discussion below). In total, 34 DEG common to the AI-IVF and AI-SCNT comparisons are specific for the long-term culture effect associated with IVF and SCNT (Fig. 2; Supplemental Table S16). These 34 DEG have significant functional associations with cell death (6 genes), posttranslational modifications (5 genes), and amino acid metabolism (3 genes). Our data are thus consistent with the hypothesis that LOS observed in IVF and SCNT pregnancies has, at least in part, a common molecular basis.

Analysis of the functional annotations of DEG in common among the IVF-AI and IVF-SCNT comparisons supports and extends previous studies of the effects of embryo culture on metabolism $(8,31)$. For the AI to IVF comparison, transcripts of genes involved in the pentose phosphate pathway (BCK$D H B$ and $A L D O C$ ) and oxidative phosphorylation (PPAI, COX6A1, and NDUFA4) were the only canonical pathways affected. COX6A1, a nuclear gene that encodes a subunit of cytochrome- $c$ oxidase, was expressed at fivefold greater levels in IVF compared with AI placentomes. These results suggest an increase in overall metabolic activity of IVF placentomes, consistent with the data of others $(7,8)$. The fact that COX6AI was among the six DEG in common between the AI-IVF and IVF-SCNT comparisons suggests that differential expression of this gene may be due to the effects of fertilization in vitro. The branched-chain keto acid dehydrogenase E1 beta polypeptide encoded by $B C K D H$ was downregulated twofold in IVF compared with AI placentomes. Mutations in $B C K D H$ are causal for Maple Syrup Urine Disease type 1B (branched-chain $\alpha$-keto dehydrogenase deficiency) in humans and cattle (24). Interestingly, $B C K D H B$ was one of four genes differentially expressed in all comparisons (Fig. 2), which suggests that embryo culture, fertilization in vitro, and SCNT all affect its expression. Finally, the nearly threefold reduced expression of $C P A 4$, an imprinted gene that may be involved in histone hyperacetylation, supports the hypothesis that embryo culture affects epigenetic modifications. Thus embryo culture clearly has long-range effects on gene expression and imprinting that are manifested in the core metabolism of placental tissues. These surprising results may have important implications for assisted reproduction in humans and in animals. Moreover, our results supply additional candidate genes and pathways to explain the relatively high frequency of LOS associated with IVF.

Genes, pathways, and networks affected by SCNT. Accumulating evidence points to a failure of complete reprogramming of the donor nucleus as a major reason for the placental defects observed after SCNT $(53,89)$. In cattle, demethylation begins after nuclear transfer and continues through the four- to eightcell stage but does not reach the level observed in embryos produced by AI $(21,89)$. Active remethylation begins at the eight-cell stage and reaches "normal" levels by the blastocyst stage (21). However, in cloned cattle and mouse embryos, methylation patterns are abnormal in the trophectoderm, lead- ing to the hypothesis that imprinting errors contribute to the placental defects observed from the preimplantation period through parturition $(55,89)$. As additional evidence in support of this hypothesis, morphometric studies clearly point to abnormalities in the formation of the trophectoderm and placenta in SCNT clones (18). These abnormalities may be extreme, especially in cases of hydrops. By comparing transcript profiles of AI, hydrops, and phenotypically normal SCNT placentomes at or near term, our study captured the molecular and biochemical features of the SCNT hydrops placenta and the possible molecular defects leading to its development.

A large fraction of DEG in the AI-SCNT comparison differed by more than twofold in their transcript levels $(n=$ $275 / 335 ; 82 \%$ ), thus demonstrating extraordinary long-term effects of SCNT on placentome gene expression. We cannot exclude the possibility that some of these differences are due to differences in embryo culture conditions (e.g., the use of oviduct cells). Although the comparison of IVF to SCNT placentomes revealed the largest number of DEG for any pairwise comparison ( $n=733,593$ unique to the IVF-SCNT comparison), the fraction more than twofold different was much lower (22\%) for the AI-IVF comparison than for the AI-SCNT comparison (82\%). Furthermore, 130 DEG in the IVF-SCNT comparison overlap with DEG in the AI-SCNT comparison (SCNT-specific set), and 35 of 40 affected IPA functional categories unique to the AI-SCNT comparison were also found for the IVF-SCNT comparison. The many shared DEG (as discussed above) and overlapping functions among the IVF and SCNT gene lists support the hypothesis that common pathways are affected by the embryo culture methods used for IVF and SCNT. However, SCNT also affects the expression of at least 202 additional genes (Fig. 2) that likely contribute to development of placental abnormalities and pathologies not observed in IVF.

Functional analysis of the large number of DEG in the SCNT-specific set (Fig. 2) is important for understanding the molecular basis for the development of placental abnormalities and hydrops. The most prominent functional effects of SCNT on placentome gene expression involved cell cycle, cell signaling, molecular transport, and DNA replication, recombination, and repair (Supplemental Table S17). All of the significantly affected molecular functions and pathways appear to be downregulated in SCNT placentomes. Many of the individual genes whose expression patterns were dramatically altered are known to have important biological effects, i.e.., in cancer, cell morphology, connective tissue development, cell growth and proliferation, and reproductive diseases. For example, LBR (lamin B receptor) is associated with Hydrops-ectopic calcification-moth-eaten, an autosomal recessive disease in humans that is characterized by fetal hydrops and short limbs. LBR transcript levels were found to be nearly fourfold greater in AI than SCNT placentomes (confirmed by qPCR; Table 4). Several genes associated with DNA replication and cell cycle were expressed at lower levels in SCNT placentomes, including $N A S P$ (nuclear autoantigenic sperm protein), a histone binding protein that has a somatic form that is expressed in all mitotic cells. NASP was downregulated $>10$-fold in SCNT placentomes. RAD51 (RAD51 homolog) was expressed at sixfold greater levels in AI than SCNT placentomes (confirmed by qPCR at 18-fold differential expression; Table 4). In yeast, Rad51 is known to be involved in homologous recombination 
and DNA repair. Similarly, HELLS, thought to encode a lymphoid-specific helicase, showed $>10$-fold increase in expression in AI compared with SCNT placentomes. HCAP-G (orthologous to human $N C A P G$ ) was expressed 16-fold greater in AI compared with SCNT placentomes. NCAPG is involved in DNA modifications, including direct interaction with DNA methyltransferase, a key enzyme involved in epigenetic modifications. These results suggest that mitotic activity is reduced or there is a loss of mitotic subpopulations of cells in SCNT placentomes. It is noteworthy that in our present comparison of $\mathrm{AI}$ and SCNT term placentas we did not find major histocompatibility complex (MHC) class I genes among the DEG. This is consistent with a recent report by Chavatte-Palmer et al. (15), who did not find differential expression of MHC class I genes, as opposed to earlier reports $(19,51)$. However, the latter studies used samples collected at day 30 to day 60 of pregnancy, whereas Chavatte-Palmer et al. (15) compared day 30 to day 60 and term samples, and our study used only samples collected at term. Thus SCNT effects on MHC class I gene expression remain to be verified.

The paradox between the occurrence of placentomegaly in SCNT and placentome gene expression associated with reduced mitotic activity and increase in apoptosis can be explained because the major period of placental growth occurs before term rather than at term, the time when our samples were collected. This is supported by the observations of Redmer et al. (71), who showed that the major period of placental growth in ruminants is during the first and second trimesters. Furthermore, it was shown that normal growth and functioning of the placenta is dependent on placental vascularization. The gross differences in gene expression patterns we observed in SCNT placentomes, including genes involved in cell signaling, cell assembly and organization, cell morphology, cell function and maintenance, and tissue-specific transcription factors (Supplemental Table S5), are consistent with the placental abnormalities (i.e., maternal epithelium thinning and mesenchyme overgrowth) observed by morphometric analysis (18). The occurrence of these abnormalities in SCNT placentas is consistent with results demonstrating that normal placental and fetal development is dependent on adequate exchange of gases and nutrients across the placenta during mid- and late gestation $(71,72)$. Effectively, a large fraction of cloned fetuses may be starved and/or accumulating toxic wastes due to placental insufficiency caused by reprogramming errors, depending on the time of onset of the placental abnormalities. This in turn may lead to embryonic and fetal morbidity and mortality. This hypothesis is supported by the decreased fetal-to-placental weight ratio in SCNT pregnancies, suggesting that placental function is affected (18). Furthermore, work on early fetal growth also showed that SCNT fetuses are growth retarded compared with AI controls in the first 2 mo of pregnancy (14).

If it is true that placental insufficiency results in hydrops and LOS in clones (5), then there should also be a metabolic footprint in SCNT placentomes. In humans, respiratory chain enzyme deficiencies are associated with clinical features similar to those observed in $\operatorname{LOS}(48,80)$. In addition, the biochemical composition of fetal fluids between day 50 and day 180 of IVF, SCNT, and AI pregnancies shows remarkable differences in the levels of glucose, fructose, and lactate in the allantoic fluid. For example, in IVF placentas glucose and fructose levels are higher than in AI placentas, whereas in SCNT placentas lactate and fructose levels are higher than in AI placentas $(8,58,70)$. Recently, it was also shown that neonatal SCNT calves have high fructose levels and low glucose and lactate levels in their blood (3). Glucose, fructose, and lactate serve as energy sources for the placenta and fetus (77), and artificial elevation of lactate levels in the fetal plasma in near-term pregnancies results in polyhydramnios and/or hydrops fetalis (70). Under normal conditions maternal glucose enters the fetal circulation through the placenta and under aerobic conditions is reduced to pyruvate. Subsequently, pyruvate enters the TCA cycle and is reduced to $\mathrm{CO}_{2}, \mathrm{H}_{2} \mathrm{O}$, and ATP by oxidative phosphorylation. Data mining revealed that seven genes involved in oxidative phosphorylation (SDHA, NDUFB5, COX6C, PPA1, UQCRC2, $A T P 5 B, N D U F A 4)$ are downregulated in SCNT placentomes. The downregulated genes are distributed over four of the five protein complexes of the oxidative phosphorylation pathway. Therefore, because of the constraints in supplying oxygen and nutrients, the anaerobic pathway may be used more in SCNT placentomes, which would result in pyruvate being reduced to lactate and less ATP production (13). In sheep, asphyxiation of the placenta for 30 min during midterm pregnancy produced phenotypes with similarities to hydrops in cattle (65). On the basis of the DEG found in the SCNT and hydrops comparisons, our data are consistent with the hypothesis that abnormal placental development in clones leads to reduced functioning of the placenta, resulting in less oxygen to the fetus. The compensatory response leading to enlarged placentomes appears to be insufficient to meet the energy demands of the growing fetus and placenta, and may lead to LOS and/or hydrops.

Construction of gene networks from the lists of DEG associated with SCNT (Fig. 3) clearly demonstrated that many DEG with known interactions associated with cell growth and proliferation, gene expression, and cell signaling are downregulated in SCNT placentomes. Hydrops thus appears to be an extreme form of the typical placental abnormalities that are observed in SCNT clones. We propose that hydrops is a manifestation of the extensive dysregulation of gene expression caused by reprogramming errors that occur during the SCNT procedure. This may involve many genes, although the same pathways appear to be consistently affected. In clones that survive to late term, the functional abnormalities may be severe enough to cause a complete breakdown in tissue homeostasis, leading to the hydrops phenotype. What tips the balance toward hydrops is unknown, but it could be related to cumulative errors in tissue function or metabolism, or perhaps other external factors.

The period prior to parturition is associated with induction of a wide array of gene expression differences in placenta $(1,29$, $41,43,85)$. This had to be taken into account in our analysis because several of the hydrops cases were preterm deliveries. Between term and preterm placentomes, 873 DEG were found, of which 61 (7\%) overlap with the AI-SCNT comparison. Functional analysis of DEG showed that cell signaling (182 genes) was a major affected category. The canonical pathway analysis complemented this view, showing mostly signalingrelated pathways, such as $I L-6, G P C R$, and integrin signaling, to be affected. In our study we found differential expression of 12 genes in the IL-6 canonical pathway, which compares favorably to other studies that showed $I L-6$ and NFKBIA to be overexpressed in human placental tissues from normal term 


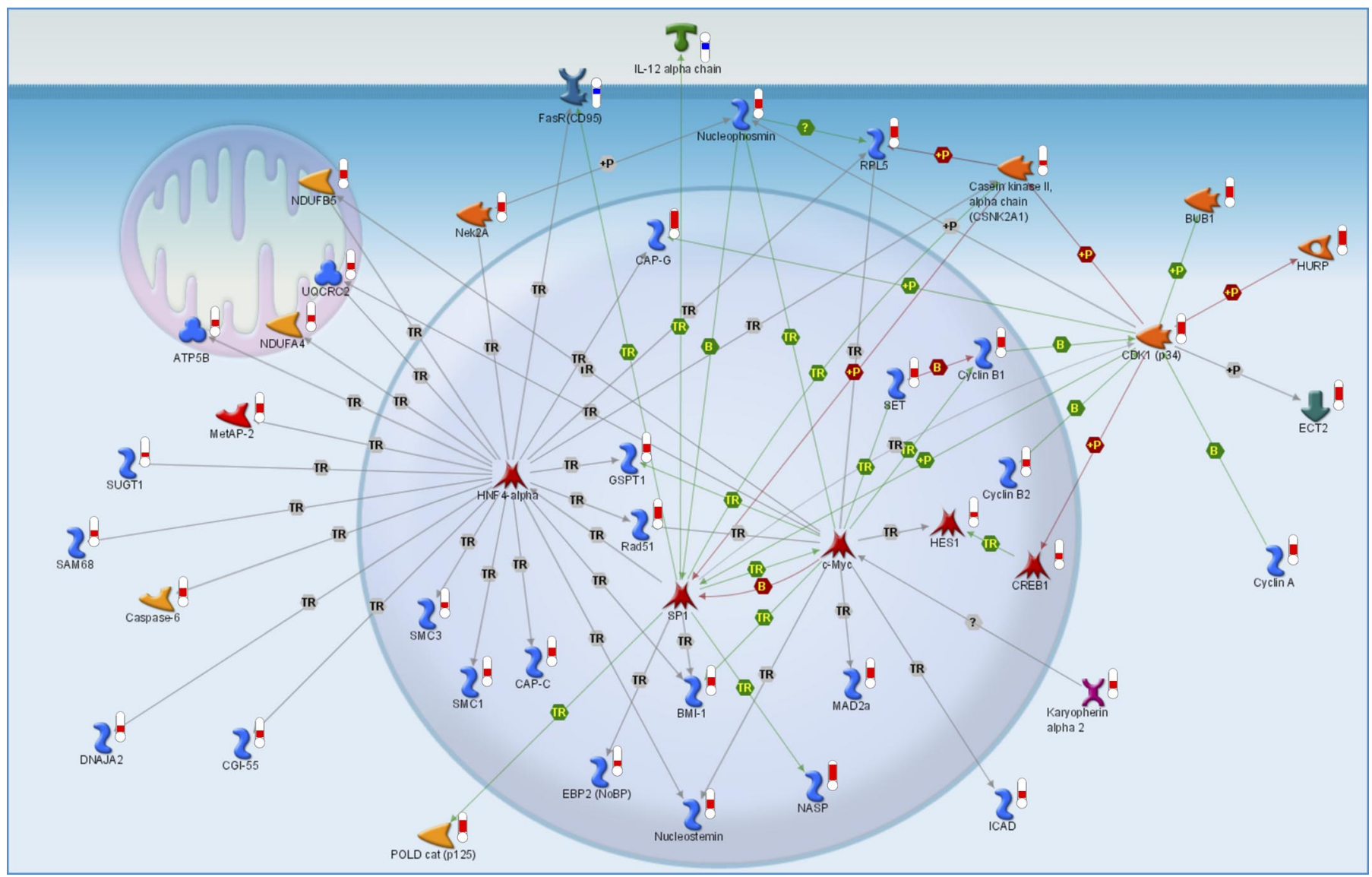

Fig. 3. Interaction network for a subset of DEG identified in the AI-SCNT comparison. Selected DEG are from the Ingenuity Pathway Assist (IPA) Bio Function categories cell cycle and cell death and the IPA canonical pathway oxidative phosphorylation. Subnetworks were identified, merged, and drawn with MetaCore by GeneGO. The "autoexpand" algorithm was employed, stopping the expansion when the subnetworks intersected. The expanded network was uploaded into GeneGO MapEditor, which allows representation of protein localization (nucleus, cytoplasm, mitochondrion, transmembrane, and extracellular). Each transcript in the DEG list is identified by a thermometer symbol. Additional proteins in the network but not represented in the DEG list have only a symbol. Red within thermometers indicates increased gene expression in AI samples, with the height of the bar representing the fold change in expression. Blue within thermometers denotes increased gene expression in SCNT samples, with the height of the bar representing the fold change in expression. Green lines denote positive effect on gene expression, whereas a red line indicates a negative effect. Gray lines denote unknown effects. A complete description of the symbols used can be obtained at http://ftp.genego.com/files/MC_legend.pdf.

labor compared with term or preterm and not in labor $(28,39$, 87). The gene CYP19A1, part of the IL-6 pathway, was increased 4-fold, and expression of PTGS2 was 20-fold greater in term placentomes compared with preterm placentomes, which is consistent with other studies and with their function in prostaglandin synthesis $(41,83)$. After 230 days of gestation, prostaglandins are essential for the promotion of myometrial contractions (83).

Another factor accounted for was sex of the calves (23 female and 15 male) because this might contribute to variation in gene expression patterns (88). The majority of the genes were upregulated in females (89\%), and most annotated genes were associated with the terms cell cycle or cellular assembly. One of the genes, $B C L 6 B$, was approximately twofold upregulated in placentomes from male fetuses. This gene is involved in spermatogonial stem cell renewal in vivo (66). The effects detected for sex were rather large, because a placentome is composed of both maternal and fetal tissue, with less than half of the tissue being of fetal origin. For this reason, the number of genes whose expression is affected by sex is probably underestimated in our study.
Overlap with genes differentially expressed in day 7 embryos. We (74) and others (69) have shown that blastocysts derived by IVF and SCNT exhibit differences in gene expression patterns. It is unknown whether these differences reflect variation that can be tolerated by the developing embryo or primary reprogramming errors that later manifest as developmental anomalies due to failure of redifferentiation (89). A comparison of 142 overlapping DEG with those found by Smith and coworkers (74) for day 7 cattle embryos revealed only seven DEG to be common for the comparison of IVF to SCNT placentomes. Two genes were in common for the comparison of AI to SCNT, but this may be due in part to the different microarray platform (7,872 cDNAs), the different donor cell lines used for SCNT, and/or the manner in which Smith et al. (74) analyzed their data. Reanalysis of the day 7 blastocyst data with the present study's statistical approach (and FDR $P<0.05$ ) uncovered 11 and 79 genes common to the IVF-AI and IVF-SCNT comparisons, respectively (data not shown). These results suggest that not all variation in SCNT embryo gene expression is lethal, and that many differences in gene expression observed in SCNT and IVF are maintained from early 
embryonic development to term despite the vastly different tissue complexity between embryos and placentomes. Those non-stage-specific genes that are differentially expressed during the zygote to blastocyst stage in SCNT embryos but not at later stages of development may be prime candidates for primary reprogramming errors that lead to early mortality and reduced cloning efficiency.

Summary. Our results provide a detailed snapshot of the underlying genes, pathways, and networks that are responsible for and associated with the placental abnormalities caused by SCNT. An extensive body of experimental evidence indicates that SCNT results in abnormal development of the placenta, which in turn leads to a high frequency of pregnancy failure at different gestational stages $(16,20,32,46,49)$. In late gestation and term SCNT cattle pregnancies, placentomegaly is highly frequent $(\sim 50 \%)$ and is characterized by hydrallantois and fetal mortality $(18,57)$. Live SCNT offspring have increased birth weight, which is correlated with placental abnormalities (18). The results of morphometric analysis were suggested to indicate that the placental abnormalities observed in SCNT result from adaptation(s) to placental dysfunction, and that dysregulation of cellular metabolism and cell signaling are responsible for these underlying defects (18). Our findings support these earlier results, but until the present study it was unclear as to whether all SCNT placentas are abnormal or only those that show gross pathological changes. We clearly demonstrated that all SCNT term and preterm placentas, whether appearing normal or not, have radically altered gene expression profiles, thus suggesting that compensatory mechanisms play a key role in overcoming fundamental defects in placental function that occur during the peri-implantation period. Predictably, clones with placentas that cannot compensate because of the cumulative effects of reprogramming errors will die, whereas those that can compensate may be abnormal yet support pregnancy to term. It is also likely that a large proportion of the clone pathologies, such as increased birth weight and hydrops, result from placental dysfunctions and not from genetic or epigenetic defects of the developing fetus. It is thus important to determine when and in what part of the developing SCNT embryo critical genes for normal development of the placenta are differentially expressed so that strategies can be devised to either avoid or correct reprogramming errors. Finally, although adult clones have been reported to be healthy, it is important to obtain long-term follow-up studies in these animals because placental abnormalities may lead to an increased incidence of metabolic pathologies later in adulthood.

\section{ACKNOWLEDGMENTS}

R. E. Everts, X. C. Tian, X. Yang, J.-P. Renard, and H. A. Lewin designed research; R. E. Everts, P. Chavatte-Palmer, I. Hue, A. Razzak, C. A. Green, R. Oliveira, and X. Vignon performed research; R. E. Everts, and H. A. Lewin contributed new reagents/analytic tools; R. E. Everts, H. A. Lewin, and S. L. Rodriguez-Zas analyzed data; and R. E. Everts and H. A. Lewin wrote the paper. All authors contributed to the editing of the paper.

\section{GRANTS}

This work was supported by US Department of Agriculture (USDA)Agricultural Research Service Contract AG 58-1265-2-020 (to H. A. Lewin), USDA-Agricultural Research Service Contract AG 58-1265-2-018 (to X. Yang, X. C. Tian), and awards from INRA No. 20058 (to J.-P. Renard) and from the French Ministry of Research No. 20085 (to I. Hue, J.-P. Renard). The support of the International Relationship Direction of INRA is warmly acknowledged.

\section{REFERENCES}

1. Aguan K, Carvajal JA, Thompson LP, Weiner CP. Application of a functional genomics approach to identify differentially expressed genes in human myometrium during pregnancy and labour. Mol Hum Reprod 6: 1141-1145, 2000.

2. Barker DJP, Eriksson JG, Forsén T, Osmond C. Fetal origins of adult disease: strength of effects and biological basis. Int J Epidemiol 31: 1235-1239, 2002.

3. Batchelder CA, Bertolini M, Mason JB, Moyer AL, Hoffert KA, Petkov SG, Famula TR, Angelos J, George LW, Anderson GB. Perinatal physiology in cloned and normal calves: physical and clinical characteristics. Cloning Stem Cells 9: 63-82, 2007.

4. Benjamini Y, Drai D, Elmer G, Kafkafi N, Golani I. Controlling the false discovery rate in behavior genetics research. Behav Brain Res 125: 279-284, 2001.

5. Bertolini M, Anderson GB. The placenta as a contributor to production of large calves. Theriogenology 57: 181-187, 2002.

6. Bertolini M, Beam SW, Shim H, Bertolini LR, Moyer AL, Famula TR, Anderson GB. Growth, development, and gene expression by in vivo- and in vitro-produced day 7 and 16 bovine embryos. Mol Reprod Dev 63: 318-328, 2002.

7. Bertolini M, Mason JB, Beam SW, Carneiro GF, Sween ML, Kominek DJ, Moyer AL, Famula TR, Sainz RD, Anderson GB. Morphology and morphometry of in vivo- and in vitro-produced bovine concepti from early pregnancy to term and association with high birth weights. Theriogenology 58: 973-994, 2002.

8. Bertolini M, Moyer AL, Mason JB, Batchelder CA, Hoffert KA, Bertolini LR, Carneiro GF, Cargill SL, Famula TR, Calvert CC, Sainz RD, Anderson GB. Evidence of increased substrate availability to in vitro-derived bovine foetuses and association with accelerated conceptus growth. Reproduction 128: 341-354, 2004.

9. Beyhan Z, Forsberg EJ, Eilertsen KJ, Kent-First M, First NL. Gene expression in bovine nuclear transfer embryos in relation to donor cell efficiency in producing live offspring. Mol Reprod Dev 74: 18-27, 2007.

10. Blelloch R, Wang Z, Meissner A, Pollard S, Smith A, Jaenisch R. Reprogramming efficiency following somatic cell nuclear transfer is influenced by the differentiation and methylation state of the donor nucleus. Stem Cells 24: 2007-2013, 2006.

11. Bourc'his D, Le Bourhis D, Patin D, Niveleau A, Comizzoli P, RenardJ-P, Viegas-Péquignot E. Delayed and incomplete reprogramming of chromosome methylation patterns in bovine cloned embryos. Curr Biol 11: 1542-1546, 2001.

12. Campbell KHS, Alberio R, Choi I, Fisher P, Kelly RDW, Lee J-H, Maalouf W. Cloning: eight years after Dolly. Reprod Domest Anim 40: 256-268, 2005.

13. Carter AM. Placental oxygen consumption. Part I: in vivo studies-a review. Placenta 21: S31-S37, 2000.

14. Chavatte-Palmer P, de Sousa N, Laigre P, Camous S, Ponter AA, Beckers J-F, Heyman Y. Ultrasound fetal measurements and pregnancy associated glycoprotein secretion in early pregnancy in cattle recipients carrying somatic clones. Theriogenology 66: 829-840, 2006.

15. Chavatte-Palmer P, Guillomot M, Roïz J, Heyman Y, Laigre P, Servely JL, Constant F, Hue I, Ellis SA. Placental expression of major histocompatibility complex class I in bovine somatic clones. Cloning Stem Cells 9: 346-356, 2007.

16. Chavatte-Palmer P, Heyman Y, Richard C, Monget P, Le Bourhis D, Kann G, Chilliard Y, Vignon X, Renard JP. Clinical, hormonal, and hematologic characteristics of bovine calves derived from nuclei from somatic cells. Biol Reprod 66: 1596-1603, 2002.

17. Chavatte-Palmer P, Remy D, Cordonnier N, Richard C, Issenman H, Laigre P, Heyman Y, Mialot J-P. Health status of cloned cattle at different ages. Cloning Stem Cells 6: 94-100, 2004.

18. Constant F, Guillomot M, Heyman Y, Vignon X, Laigre P, Servely JL, Renard JP, Chavatte-Palmer P. Large offspring or large placenta syndrome? Morphometric analysis of late gestation bovine placentomes from somatic nuclear transfer pregnancies complicated by hydrallantois. Biol Reprod 75: 122-130, 2006.

19. Davies CJ, Eldridge JA, Fisher PJ, Schlafer DH. Evidence for expression of both classical and non-classical major histocompatibility complex class I genes in bovine trophoblast cells. Am J Reprod Immunol 55: 188-200, 2006. 
20. De Sousa PA, King T, Harkness L, Young LE, Walker SK, Wilmut I. Evaluation of gestational deficiencies in cloned sheep fetuses and placentae. Biol Reprod 65: 23-30, 2001.

21. Dean W, Santos F, Reik W. Epigenetic reprogramming in early mammalian development and following somatic nuclear transfer. Semin Cell Dev Biol 14: 93-100, 2003.

22. De Baun MR, Niemitz EL, Feinberg AP. Association of in vitro fertilization with Beckwith-Wiedemann Syndrome and epigenetic alterations of LIT1 and H19. Am J Hum Genet 72: 156-160, 2003.

23. Delaval K, Wagschal A, Feil R. Epigenetic deregulation of imprinting in congenital diseases of aberrant growth. Bioessays 28: 453-459, 2006.

24. Dennis JA, Healy PJ. Definition of the mutation responsible for maple syrup urine disease in Poll Shorthorns and genotyping Poll Shorthorns and Poll Herefords for maple syrup urine disease alleles. Res Vet Sci 67: 1-6, 1999.

25. Doherty AS, Mann MRW, Tremblay KD, Bartolomei MS, Schultz RM. Differential effects of culture on imprinted H19 expression in the preimplantation mouse embryo. Biol Reprod 62: 1526-1535, 2000.

26. Ecker DJ, Stein P, Xu Z, Williams CJ, Kopf GS, Bilker WB, Abel T, Schultz RM. Long-term effects of culture of preimplantation mouse embryos on behavior. Proc Natl Acad Sci USA 101: 1595-1600, 2004.

27. Edwards JL, Schrick FN, McCracken MD, van Amstel SR, Hopkins FM, Welborn MG, Davies CJ. Cloning adult farm animals: a review of the possibilities and problems associated with somatic cell nuclear transfer. Am J Reprod Immunol 50: 113-123, 2003.

28. El-Shazly S, Makhseed M, Azizieh F, Raghupathy R. Increased expression of pro-inflammatory cytokines in placentas of women undergoing spontaneous preterm delivery or premature rupture of membranes. Am J Reprod Immunol 52: 45-52, 2004.

29. Esplin MS, Fausett MB, Peltier MR, Hamblin S, Silver RM, Branch DW, Adashi EY, Whiting D. The use of cDNA microarray to identify differentially expressed labor-associated genes within the human myometrium during labor. Am J Obstet Gynecol 193: 404-413, 2005.

30. Everts RE, Band MR, Liu ZL, Kumar CG, Liu L, Loor JJ, Oliveira R, Lewin HA. A 7872 cDNA microarray and its use in bovine functional genomics. Vet Immunol Immunopathol 105: 235-245, 2005.

31. Farin PW, Crosier AE, Farin CE. Influence of in vitro systems on embryo survival and fetal development in cattle. Theriogenology 55: 151-170, 2001.

32. Farin PW, Piedrahita JA, Farin CE. Errors in development of fetuses and placentas from in vitro-produced bovine embryos. Theriogenology 65 : 178-191, 2006.

33. Fernández-Gonzalez R, Moreira P, Bilbao A, Jiménez A, Pérez-Crespo M, Ramírez MA, Rodríguez De Fonseca F, Pintado B, Gutiérrez-Adán A. Long-term effect of in vitro culture of mouse embryos with serum on mRNA expression of imprinting genes, development, and behavior. Proc Natl Acad Sci USA 101: 5880-5885, 2004.

34. Fletcher CJ, Roberts CT, Hartwich KM, Walker SK, McMillen IC. Somatic cell nuclear transfer in the sheep induces placental defects that likely precede fetal demise. Reproduction 133: 243-255, 2007.

35. Gardner DK. Development of serum-free media for the culture and transfer of human blastocysts. Hum Reprod 13, Suppl 4: 218-225, 1998.

36. Giritharan G, Talbi S, Donjacour A, Di Sebastiano F, Dobson AT, Rinaudo PF. Effect of in vitro fertilization on gene expression and development of mouse preimplantation embryos. Reproduction 134: 63 72, 2007

37. Gluckman PD, Hanson MA. Living with the past: evolution, development, and patterns of disease. Science 305: 1733-1736, 2004.

38. Gosden R, Trasler J, Lucifero D, Faddy M. Rare congenital disorders, imprinted genes, and assisted reproductive technology. Lancet 361: 19751977, 2003.

39. Haddad R, Tromp G, Kuivaniemi H, Chaiworapongsa T, Kim YM, Mazor M, Romero R. Human spontaneous labor without histologic chorioamnionitis is characterized by an acute inflammation gene expression signature. Am J Obstet Gynecol 195: 394-24, 2006.

40. Hashizume K, Ishiwata H, Kizaki K, Yamada O, Takahashi T, Imai K, Patel OV, Akagi S, Shimizu M, Takahashi S, Katsuma S, Shiojima S, Hirasawa A, Tsujimoto G, Todoroki J, Izaike Y. Implantation and placental development in somatic cell clone recipient cows. Cloning Stem Cells 4: 197-209, 2002.

41. Havelock JC, Keller P, Muleba N, Mayhew BA, Casey BM, Rainey WE, Word RA. Human myometrial gene expression before and during parturition. Biol Reprod 72: 707-719, 2005.
42. Herath CB, Ishiwata H, Shiojima S, Kadowaki T, Katsuma S, Ushizawa K, Imai K, Takahashi T, Hirasawa A, Takahashi S, Izaike Y, Tsujimoto G, Hashizume K. Developmental aberrations of liver gene expression in bovine fetuses derived from somatic cell nuclear transplantation. Cloning Stem Cells 8: 79-95, 2006.

43. Herse F, Dechend R, Harsem NK, Wallukat G, Janke J, Qadri F, Hering L, Muller DN, Luft FC, Staff AC. Dysregulation of the circulating and tissue-based renin-angiotensin system in preeclampsia. Hypertension 49: 604-611, 2007.

44. Heyman Y. Nuclear transfer: a new tool for reproductive biotechnology in cattle. Reprod Nutr Dev 45: 353-361, 2005.

45. Heyman Y, Chavatte-Palmer P, Fromentin G, Berthelot V, Jurie C, Bas P, Dubarry M, Mialot JP, Remy D, Richard C, Martignat L, Vignon X, Renard JP. Quality and safety of bovine clones and their products. Animal 1: 963-972, 2007.

46. Heyman Y, Chavatte-Palmer P, Le Bourhis D, Camous S, Vignon X, Renard JP. Frequency and occurrence of late-gestation losses from cattle cloned embryos. Biol Reprod 66: 6-13, 2002.

47. Heyman Y, Richard C, Rodriguez-Martinez H, Lazzari G, ChavattePalmer P, Vignon X, Galli C. Zootechnical performance of cloned cattle and offspring: preliminary results. Cloning Stem Cells 6: 111-120, 2004.

48. Hiendleder S, Zakhartchenko V, Wolf E. Mitochondria and the success of somatic cell nuclear transfer cloning: from nuclear-mitochondrial interactions to mitochondrial complementation and mitochondrial DNA recombination. Reprod Fertil Dev 17: 69-83, 2005.

49. Hill JR, Burghardt RC, Jones K, Long CR, Looney CR, Shin T, Spencer TE, Thompson JA, Winger QA, Westhusin ME. Evidence for placental abnormality as the major cause of mortality in first-trimester somatic cell cloned bovine fetuses. Biol Reprod 63: 1787-1794, 2000.

50. Hill JR, Edwards JF, Sawyer N, Blackwell C, Cibelli JB. Placental anomalies in a viable cloned calf. Cloning 3: 83-88, 2001.

51. Hill JR, Schlafer DH, Fisher PJ, Davies CJ. Abnormal expression of trophoblast major histocompatibility complex class I antigens in cloned bovine pregnancies is associated with a pronounced endometrial lymphocytic response. Biol Reprod 67: 55-63, 2002.

52. Hochedlinger K, Jaenisch R. Nuclear reprogramming and pluripotency. Nature 441: 1061-1067, 2006.

53. Jouneau A, Zhou Q, Camus A, Brochard V, Maulny L, Collignon J, Renard J-P. Developmental abnormalities of NT mouse embryos appear early after implantation. Development 133: 1597-1607, 2006.

54. Kang Y-K, Koo D-B, Park J-S, Choi Y-H, Chung A-S, Lee K-K, Han Y-M. Aberrant methylation of donor genome in cloned bovine embryos. Nat Genet 28: 173-177, 2001.

55. Kang Y-K, Park JS, Koo D-B, Choi Y-H, Kim S-U, Lee K-K, Han Y-M. Limited demethylation leaves mosaic-type methylation states in cloned bovine pre-implantation embryos. EMBO J 21: 1092-1100, 2002.

56. Koo D-B, Kang Y-K, Choi Y-H, Park JS, Kim H-N, Oh KB, Son D-S, Park H, Lee K-K, Han Y-M. Aberrant allocations of inner cell mass and trophectoderm cells in bovine nuclear transfer blastocysts. Biol Reprod 67: 487-492, 2002.

57. Lee RSF, Peterson AJ, Donnison MJ, Ravelich S, Ledgard AM, Li N, Oliver JE, Miller AL, Tucker FC, Breier B, Wells DN. Cloned cattle fetuses with the same nuclear genetics are more variable than contemporary half-siblings resulting from artificial insemination and exhibit fetal and placental growth deregulation even in the first trimester. Biol Reprod 70: 1-11, 2004.

58. Li N, Wells DN, Peterson AJ, Lee RSF. Perturbations in the biochemical composition of fetal fluids are apparent in surviving bovine somatic cell nuclear transfer pregnancies in the first half of gestation. Biol Reprod 73: 139-148, 2005.

59. Loi P, Clinton M, Vackova I, Fulka J Jr, Feil R, Palmieri C, Della Salda L, Ptak G. Placental abnormalities associated with post-natal mortality in sheep somatic cell clones. Theriogenology 65: 1110-1121, 2006

60. Loor JJ, Dann HM, Everts RE, Oliveira R, Green CA, Janovick Guretzky NA, Rodriguez-Zas SL, Lewin HA, Drackley JK. Temporal gene expression profiling of liver from periparturient dairy cows reveals complex adaptive mechanisms in hepatic function. Physiol Genomics 23: 217-226, 2005.

61. Loor JJ, Everts RE, Bionaz M, Dann HM, Morin DE, Oliveira R, Rodriguez-Zas SL, Drackley JK, Lewin HA. Nutrition-induced ketosis alters metabolic and signaling gene networks in liver of periparturient dairy cows. Physiol Genomics 32: 105-116, 2007. 
62. MacDougall MWJ, Europe-Finner GN, Robson SC. Human myometrial quiescence and activation during gestation and parturition involve dramatic changes in expression and activity of particulate type II (RII $\alpha$ ) protein kinase A holoenzyme. J Clin Endocrinol Metab 88: 2194-2205, 2003.

63. Meissner A, Jaenisch R. Mammalian nuclear transfer. Dev Dyn 235: 2460-2469, 2006.

64. Moll AC, Imhof SM, Cruysberg JRM, Schouten-van Meeteren AYN, Boers M, van Leeuwen FE. Incidence of retinoblastoma in children born after in-vitro fertilisation. Lancet 361: 309-310, 2003.

65. O'Connell AE, Boyce AC, Kumarasamy V, Douglas-Denton R, Bertram JF, Gibson KJ. Long-term effects of a midgestational asphyxial episode in the ovine fetus. Anat Rec A Discov Mol Cell Evol Biol 288A: 1112-1120, 2006.

66. Oatley JM, Avarbock MR, Telaranta AI, Fearon DT, Brinster RL. Identifying genes important for spermatogonial stem cell self-renewal and survival. Proc Natl Acad Sci USA 103: 9524-9529, 2006.

67. Ogura A, Inoue K, Ogonuki N, Lee J, Kohda T, Ishino F. Phenotypic effects of somatic cell cloning in the mouse. Cloning Stem Cells 4: 397-405, 2002.

68. Oishi M, Gohma H, Hashizume K, Taniguchi Y, Yasue H, Takahashi S, Yamada T, Sasaki Y. Early embryonic death-associated changes in genome-wide gene expression profiles in the fetal placenta of the cow carrying somatic nuclear-derived cloned embryo. Mol Reprod Dev 73: 404-409, 2006.

69. Pfister-Genskow M, Myers C, Childs LA, Lacson JC, Patterson T, Betthauser JM, Goueleke PJ, Koppang RW, Lange G, Fisher P, Watt SR, Forsberg EJ, Zheng Y, Leno GH, Schultz RM, Liu B, Chetia C, Yang X, Hoeschele I, Eilertsen KJ. Identification of differentially expressed genes in individual bovine preimplantation embryos produced by nuclear transfer: improper reprogramming of genes required for development. Biol Reprod 72: 546-555, 2005.

70. Powell TL, Brace RA. Elevated fetal plasma lactate produces polyhydramnios in the sheep. Am J Obstet Gynecol 165: 1595-1607, 1991.

71. Redmer DA, Wallace JM, Reynolds LP. Effect of nutrient intake during pregnancy on fetal and placental growth and vascular development. Domest Anim Endocrinol 27: 199-217, 2004.

72. Reynolds LP, Redmer DA. Utero-placental vascular development and placental function. J Anim Sci 73: 1839-1851, 1995.

73. SAS Institute. SAS Online Doc 9.1.3. Cary, NC: SAS Institute, 2007.

74. Smith SL, Everts RE, Tian XC, Du F, Sung L-Y, Rodriguez-Zas S, Jeong B-S, Renard JP, Lewin HA, Yang X. Global gene expression profiles reveal significant nuclear reprogramming by the blastocyst stage after cloning. Proc Natl Acad Sci USA 102: 17582-17587, 2005.

75. Somers J, Smith C, Donnison M, Wells DN, Henderson H, McLeay L, Pfeffer PL. Gene expression profiling of individual bovine nuclear transfer blastocysts. Reproduction 131: 1073-1084, 2006.

76. Sood R, Zehnder JL, Druzin ML, Brown PO. Gene expression patterns in human placenta. Proc Natl Acad Sci USA 103: 5478-5483, 2006.

77. Sparks JW, Hay WW Jr, Bonds D, Meschia G, Battaglia FC. Simultaneous measurements of lactate turnover rate and umbilical lactate uptake in the fetal lamb. J Clin Invest 70: 179-192, 1982.

78. Tamashiro KLK, Wakayama T, Blanchard RJ, Blanchard DC, Yanagimachi R. Postnatal growth and behavioral development of mice cloned from adult cumulus cells. Biol Reprod 63: 328-334, 2000.
79. Tian XC, Kubota C, Sakashita K, Izaike Y, Okano R, Tabara N, Curchoe C, Jacob L, Zhang Y, Smith S, Bormann C, Xu J, Sato M, Andrew S, Yang X. Meat and milk compositions of bovine clones. Proc Natl Acad Sci USA 102: 6261-6266, 2005.

79a.Vignon X, Chesné P, Le Bourhis D, Fléchon JE, Heyman Y, Renard JP. Developmental potential of bovine embryos reconstructed from enucleated matured oocytes fused with cultured somatic cells. C R Acad Sci III 321: 735-745, 1998 .

80. von Kleist-Retzow J-C, Cormier-Daire V, Viot G, Goldenberg A, Mardach B, Amiel J, Saada P, Dumez Y, Brunelle F, Saudubray J-M, Chretien D, Rotig A, Rustin P, Munnich A, De Lonlay P. Antenatal manifestations of mitochondrial respiratory chain deficiency. J Pediatr 143: 208-212, 2003.

81. Walker SK, Hartwich KM, Seamark RF. The production of unusually large offspring following embryo manipulation: concepts and challenges. Theriogenology 45: 111-120, 1996.

82. Walsh MK, Lucey JA, Govindasamy-Lucey S, Pace MM, Bishop MD. Comparison of milk produced by cows cloned by nuclear transfer with milk from non-cloned cows. Cloning Stem Cells 5: 213-219, 2003.

83. Wehbrink D, Hässig M, Ritter N, Zerbe H, Bleul U, Boos A. Immunohistochemical demonstration of cyclooxygenase-2 (COX-2) and prostaglandin receptors $\mathrm{EP}_{2}$ and $\mathrm{FP}$ expression in the bovine intercaruncular uterine wall around term. Anim Reprod Sci 2007.

84. Wilmut I, Schnieke AE, McWhir J, Kind AJ, Campbell KHS. Viable offspring derived from fetal and adult mammalian cells. Nature 385: 810-813, 1997.

85. Winn VD, Haimov-Kochman R, Paquet AC, Yang YJ, Madhusudhan MS, Gormley M, Feng K-TV, Bernlohr DA, McDonagh S, Pereira L, Sali A, Fisher SJ. Gene expression profiling of the human maternal-fetal interface reveals dramatic changes between midgestation and term. Endocrinology 148: 1059-1079, 2007.

86. Wolfinger RD, Gibson G, Wolfinger ED, Bennett L, Hamadeh H, Bushel P, Afshari C, Paules RS. Assessing gene significance from cDNA microarray expression data via mixed models. J Comput Biol 8: 625-637, 2001.

87. Yan X, Sun M, Gibb W. Localization of nuclear factor-кB (NFкB) and inhibitory factor- $\kappa \mathrm{B}(\mathrm{I} \kappa \mathrm{B})$ in human fetal membranes and decidua at term and preterm delivery. Placenta 23: 288-293, 2002.

88. Yang X, Schadt EE, Wang S, Wang H, Arnold AP, Ingram-Drake L, Drake TA, Lusis AJ. Tissue-specific expression and regulation of sexually dimorphic genes in mice. Genome Res 16: 995-1004, 2006.

89. Yang X, Smith SL, Tian XC, Lewin HA, Renard J-P, Wakayama T. Nuclear reprogramming of cloned embryos and its implications for therapeutic cloning. Nat Genet 39: 295-302, 2007.

90. Yang X-y, Li H, Ma Q-w, Yan J-b, Zhao J-g, Li HW, Shen H-q, Liu H-f, Huang Y, Huang S-Z, Zeng Y-T, Zeng F. Improved efficiency of bovine cloning by autologous somatic cell nuclear transfer. Reproduction 132: 733-739, 2006.

91. Young LE, Fairburn HR. Improving the safety of embryo technologies: possible role of genomic imprinting. Theriogenology 53: 627-648, 2000.

92. Young LE, Sinclair KD, Wilmut I. Large offspring syndrome in cattle and sheep. Rev Reprod 3: 155-163, 1998. 